\title{
Impact of Macroeconomic Condition on Credit Card Default in Emerging Economy: Empirical Evidence from Indonesia
}

\author{
Wahid Achsan, Noer Azam Achsani, Bayu Bandono \\ School of Business, IPB University, Bogor, Indonesia \\ Email address: \\ achsanwahid@gmail.com (W. Achsan)

\section{To cite this article:} \\ Wahid Achsan, Noer Azam Achsani, Bayu Bandono. Impact of Macroeconomic Condition on Credit Card Default in Emerging Economy: \\ Empirical Evidence from Indonesia. International Journal of Finance and Banking Research. Vol. 6, No. 3, 2020, pp. 37-43. \\ doi: $10.11648 /$ j.jifbr.20200603.11
}

Received: March 27, 2020; Accepted: April 29, 2020; Published: May 15, 2020

\begin{abstract}
Indonesia is a developing country with the fourth largest population in the world. Household consumption is still the main pillar of national economic growth in Indonesia. One sector that has an important role in national economic growth is banking. Bank carries out an intermediary function that directly or indirectly can encourage the real sector. A credit card is one of the banking products that can encourage growth in household consumption to support the growth of the real sector. However, on the other hand, the credit card is an unsecured consumer loan. This indicates the bank will have a greater percentage of losses than other types of credit if the borrower default. Therefore, the growth of credit card business must be balanced with good credit quality for the safety and soundness of the banking sector. Credit quality can be measured using a Non-Performing Loan (NPL) that reflects credit default risk. This study aimed to analyze the impact of the macroeconomic condition on credit card default which is proxied by credit card NPL ratio. NPL data obtained from Indonesia's biggest private bank with cardholders that are widespread on every island and have average card growth, transaction value, and outstanding credit card were above the national average. ARDL Cointegration model is used to determine macroeconomic variables that significantly affect credit card NPL. This study was found that exchange rate and interest rate variables partially have a significant influence on the credit card NPL in the long-term. ARDL model can be used as an early warning indicator of the condition of Bank credit card NPL if there is a shock to macroeconomic variables and the model can be used to improve the feasibility analysis tool for new cardholders (credit scoring system) and an indicator of behavior scoring system for existing cardholders.
\end{abstract}

Keywords: ARDL Model, Credit Card, Macroeconomic, Non-Performing Loan

\section{Introduction}

Indonesia is a developing country with the fourth largest population in the world (264,2 million in December 2018). Indonesia's Gross Domestic Product (GDP) in 2018 increased $8.85 \%$ from the previous year to IDR 3,798,675 billion. Until December 2018, household consumption is still the main pillar of national economic growth $(55.7 \%$ of Gross Domestic Product). Household consumption expenditure in quarter IV 2018 grew 5.08\% compared to quarter IV 2017.

One sector that has an important role in national economic growth is banking. Bank carries out an intermediary function that directly or indirectly can encourage the real sector. A credit card is one of the banking products that can encourage growth in household consumption to support the growth of the real sector. The value of credit card transactions in 2018 grew by $5,55 \%$ from the previous year. This is in line with the positive growth in household consumption and the national economy.

A credit card makes it easy for cardholders to make payments for purchase made. Cardholders do not need cash and payment transaction purchase are made by the credit card issuer first. Cardholders are obliged to pay off the issuer at the agreed time, both at once or in installments. A credit card also makes it easy for cardholders to take cash at an ATM (Automated Teller Machine). Besides, According to the Central Bank of Indonesia (BI) regulation No. 18/33/DKSP on 2, December 2016 it reduced the maximum limit on credit card interest rates from $2.95 \%$ to $2.25 \%$ per month. This will ease the burden on cardholders when bill payments are not made in full payment.

A credit card is an unsecured consumer loan offered by 
banks [1]. This indicates the bank will have a greater percentage of losses than other types of credit if the borrower default. Therefore, the growth of credit card business must be balanced with good credit quality.

According to Central Bank of Indonesia (BI) regulation No. $14 / 15 / \mathrm{PBI} / 2012$ bank credit quality is grouped into five, consisting of current (L), special attention (DPK), substandard (KL), doubtful (D), and bad (M). Credit quality can be measured using a Non-Performing Loan (NPL). NPL is a ratio of outstanding loans that are substandard, doubtful, and bad to total loans. Therefore, NPL can reflect credit default risk.

Credit card NPL in Indonesia increased from $1.20 \%$ in 2014 to $2.01 \%$ in 2018 . This condition is generally influenced by an internal and external factor. Internal factors such as management business decisions, internal policy, human resources allocation. Meanwhile, external factors may come from such as regulation and macroeconomic factors either in domestic and international.

According to the description above, the Bank needs to understand the factors that affect the credit card NPL. By understanding the factors that influence the level of NPL, credit quality and bank soundness can be maintained so that the growth of the credit card business can provide long-term benefits for banks.

The purposes of this study were limited to analyze macroeconomic conditions that have an impact on credit card NPL through several determined variables. This study is carried out to the stage of providing managerial recommendations for controlling credit card NPL.

\section{Literature Review}

Some previous study has been conducted to examine the macroeconomic factor that significantly affects the credit quality of the credit card. Various macroeconomic variables that have been used in the previous study were diverse, but several common such as inflation, interest rate, exchange rate, gross domestic product, stock price index, and unemployment rate.

GDP was the significant variable affecting the level of credit card NPL [2, 3, 4]. Declining GDP Growth will increase credit card NPL. Besides, GDP growth rate is an important determinant of NPL in Bangladesh, The GDP growth rate also should be taken into consideration by the Banks while increasing their loan portfolio [5]. Meanwhile, the stock price index also has a significant relationship to the credit card NPL [4]. According study result $[6,7]$, there is strong evidence that interest rate has a positive significance affecting credit card NPL.

Unemployment rate was the significant variable that affecting the level of credit card NPL [2, 3, 8-11]. The high unemployment rate will increase credit card NPL.

A study on macroeconomic factors affecting credit card default in Indonesia uses one of a state-owned commercial bank with an analysis method using multiple linear regression [12]. The result of the study shows variables interest rate, inflation, exchange rate, and stock price index significantly affect credit card NPL.

The difference between this study and the previous study lies in the bank used as the object of the study, the macroeconomic variables to be analyzed and the analytical methods used. This study using the Autoregressive Distributed Lag (ARDL) Cointegration model. This model can distinguish the short-term and long-term responses of the dependent variable to a unit of change in the value of the independent variable [13].

\section{Research Method}

The object under study is a credit card product from the biggest private bank in Indonesia with average card growth, transaction value, and outstanding credit card were above the national average (Table 1$)$.

Table 1. Growth of Card Number, Transaction Value, and Outstanding Credit Card (2014-2018).

\begin{tabular}{lcccccc}
\hline & \multicolumn{2}{c}{ Growth (\%) } & \multicolumn{3}{l}{ Average (\%) } \\
\cline { 2 - 7 } & $\mathbf{2 0 1 4}$ & $\mathbf{2 0 1 5}$ & $\mathbf{2 0 1 6}$ & $\mathbf{2 0 1 7}$ & $\mathbf{2 0 1 8}$ \\
\hline \multicolumn{2}{l}{ Number of Cards } & & & & & \\
National & 6.31 & 5.11 & 3.22 & -0.93 & 0.18 & 2.78 \\
$\begin{array}{l}\text { Bank } \\
\text { Transaction Value }\end{array}$ & 5.09 & 6.39 & 8.55 & 10.49 & 9.50 & 8.00 \\
National & 14.19 & 9.99 & 0.17 & 5.96 & 5.55 & 7.17 \\
Bank & 17.90 & 9.76 & 6.13 & 13.41 & 14.45 & 12.33 \\
Outstanding & & & & & & \\
National & 22.57 & 12.00 & 7.16 & 4.63 & 1.38 & 9.55 \\
Bank & 18.35 & 8.10 & 13.71 & 6.96 & 11.80 & 11.78 \\
\hline
\end{tabular}

Furthermore, during 2014 - June 2019, the trend of credit card NPL has increased and always higher than NPL of total credit Bank (Figure 2). The research design approach uses causal research which aims to determine the influencing factors in a study.

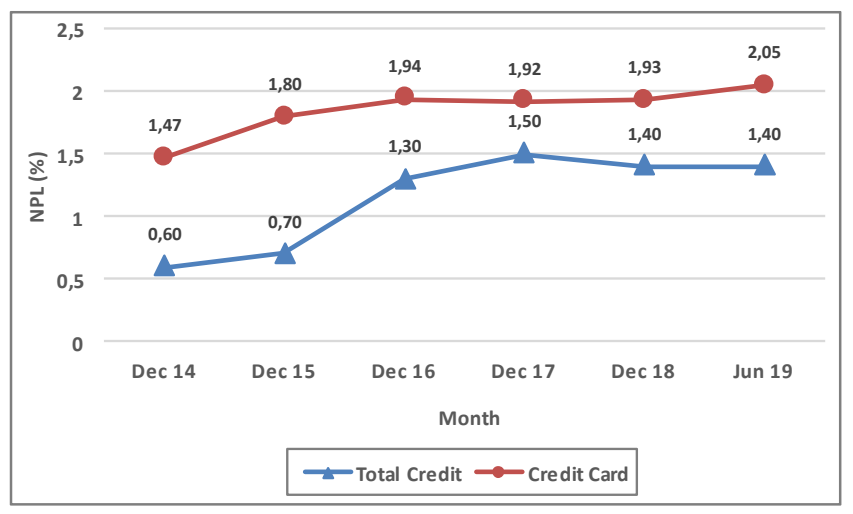

Figure 1. NPL Credit Card and Total Credit Bank.

\subsection{Research Data and Variables}

The study was conducted using secondary data sourced from Bank, Central Bank of Indonesia (BI), The Jakarta Stock Exchange, and The Central Bureau of Statistics (BPS). Macroeconomic factor analysis uses monthly data from June 2012 - June 2019. Variable dependent is credit card NPL Bank and independent variable consisting of Consumer Prices Index (CPI), BI Rate (BIR), IDR Exchange Rate against US Dollar (EXH), Industrial Production Index (IPI), 
and Jakarta Stock Price Index (IHG).

\subsection{ARDL Cointegration Model}

ARDL Cointegration is used to find out the macroeconomic factors that significantly affect credit card NPL. The Autoregressive Model (AR) is a model that uses one or more past data from the dependent variable among the independent variables. Distributed Lag (DL) model is a regression model that involves data on the present and past time (lagged) of the independent variables. This model can distinguish the short-term and long-term responses of the dependent variable to a unit of change in the value of the independent variable [13]. Therefore, ARDL Cointegration is a regression model that incorporates the time influence of the independent and dependent variables simultaneously. ARDL Cointegration model for macroeconomic factors that affect credit card NPL as follows:

$$
\Delta Y_{t}=a+\sum_{j=1}^{n} b 1_{j} \Delta Y_{t-j}+\sum_{j=1}^{n} b 2_{j} \Delta X 1_{t-j}+\cdots+\sum_{j=1}^{n} b k_{j} \Delta X m_{t-j}+\beta_{1} Y_{t-1}+\beta_{2} X 1_{t-1}+\cdots+\beta_{l} X m_{t-1}+\varepsilon_{t}
$$

Notes:

$\Delta=$ First difference variable

$\mathrm{a}=$ Constant

$b=$ Short-term coefficient variable

$\beta=$ Long-term coefficient variable

$\varepsilon=$ Error

$\mathrm{t}=$ Time period (month)

$\mathrm{j}=$ Lag variables

$\mathrm{Y}=$ Independent Variable

$\mathrm{X}=$ Dependent Variable

\section{Result and Discussion}

Analysis of macroeconomic factors that affect credit card NPL uses an independent variable consisting of Consumer Prices Index (CPI), BI Rate (BIR), IDR Exchange Rate against US Dollar (EXH), Industrial Production Index (IPI), and Jakarta Stock Price Index (IHG).

Stationarity Test

The main time series data analysis requirement on each data that is done is stationary. The requirement to use ARDL Cointegration is the variables must be stationary at the data level, first difference / I (1), or a combination of both [14]. The results of data stationarity testing using the Augmented Dickey-Fuller (ADF) test shows that all variables consisting of NPL, CPI, BIR, EXH, IPI, and IHG stationary at the first difference (Table 2). This is indicated from the level significance (Prob.) of all variables at first difference $\leq 0.05$.

Table 2. Stationarity Test.

\begin{tabular}{lllll}
\hline \multirow{2}{*}{ Variable } & \multicolumn{2}{l}{ Level } & \multicolumn{3}{c}{ First Difference } \\
\cline { 2 - 5 } & T-statistic & Prob. & T-statistic & Prob. \\
\hline NPL & -1.689470 & 0.4329 & -1.139454 & 0.0001 \\
CPI & -1.885463 & 0.3376 & -9.038653 & 0.0000 \\
BIR & -1.214836 & 0.6648 & -5.911413 & 0.0000 \\
EXH & -1.796759 & 0.3798 & -1.009910 & 0.0000 \\
IPI & 0.504141 & 0.9858 & -7.045158 & 0.0000 \\
IHG & -1.261206 & 0.6442 & -7.791333 & 0.0000 \\
\hline
\end{tabular}

Optimal Lag Test

The optimum lag test is used to avoid autocorrelation on the model. The best lag combination is chosen based on the smallest value of Akaike Information Criteria - AIC [15]. Based on the optimum lag test results, the best lag combination that can be used in the model is $\operatorname{ARDL}(5,0,4,7$,
$4,0)$. The optimum lag test results based on AIC values can be seen in Figure 2.

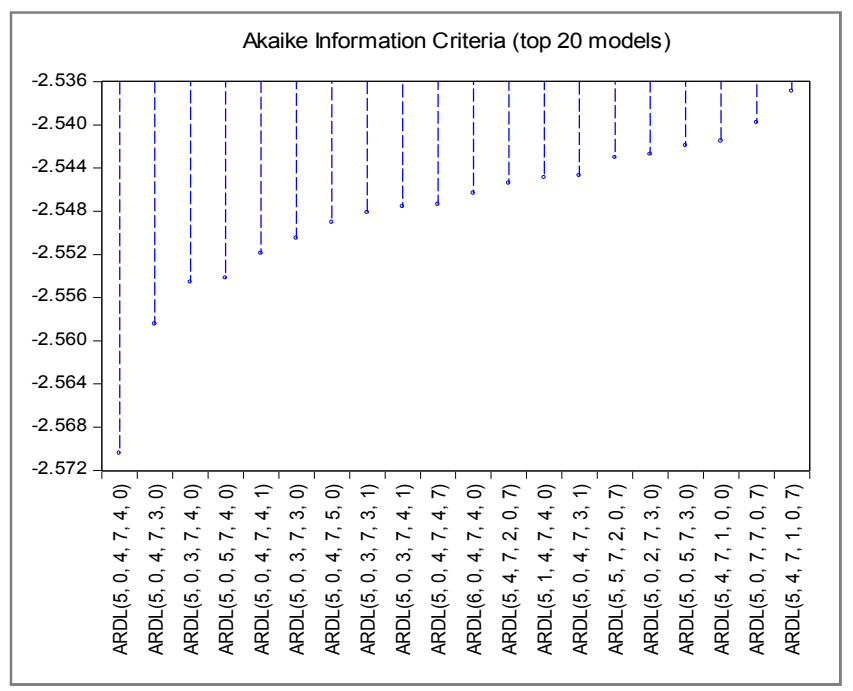

Figure 2. Optimum Lag Test Result.

\section{Cointegration Test}

In the ARDL model, the cointegration test uses the Bound Test [16]. Cointegration test results based on Bound test approach (Table 3) shows F-statistic value is above the upper bound at the level of significance $2.5 \%$, so it can be concluded cointegration occurs between variables used in the ARDL model $(5,0,4,7,4,0)$. This means, there is a balance from the short-term to the long-term on these variables.

Table 3. Cointegration Test Result.

\begin{tabular}{lll}
\hline Test Statistic & Value & K \\
\hline F-statistic & 4.525343 & 5 \\
Critical Value Bounds & & \\
Significance & I (0) Bound & I (1) Bound \\
$10 \%$ & 2.26 & 3.35 \\
$5 \%$ & 2.62 & 3.79 \\
$2,5 \%$ & 2.96 & 4.18 \\
$1 \%$ & 3.41 & 4.68 \\
\hline
\end{tabular}

Model Goodness Test

The goodness of the model test is conduct to detect whether the model occurs autocorrelation, heteroscedasticity, non-normality, and non-linearity. Model goodness test results in Table 4. 
Table 4. Model Goodness Test Result.

\begin{tabular}{llll}
\hline Testing & Statistic Test & Prob. & Conclusion \\
\hline Lagrange Multiplier (LM) & 0.187915 & 0.8293 & No autocorrelation \\
Park Gleyser & 0.961953 & 0.5284 & Homoscedastisity \\
Jarque-Bera & 2.915066 & 0.2328 & Normal Distribution \\
Ramsey RESET & 0.997879 & 0.3225 & Linear Model \\
\hline
\end{tabular}

\section{Stability Test}

The method used to test the stability of the model is the Cumulative Sum (CUSUM) of Recursive Residuals and CUSUM of square (CUSUMSQ) [17]. The results show that the CUSUM and CUSUMSQ charts are in the 5\% significance area (Figure 3). Therefore, the model is stable in both the short and long-term.

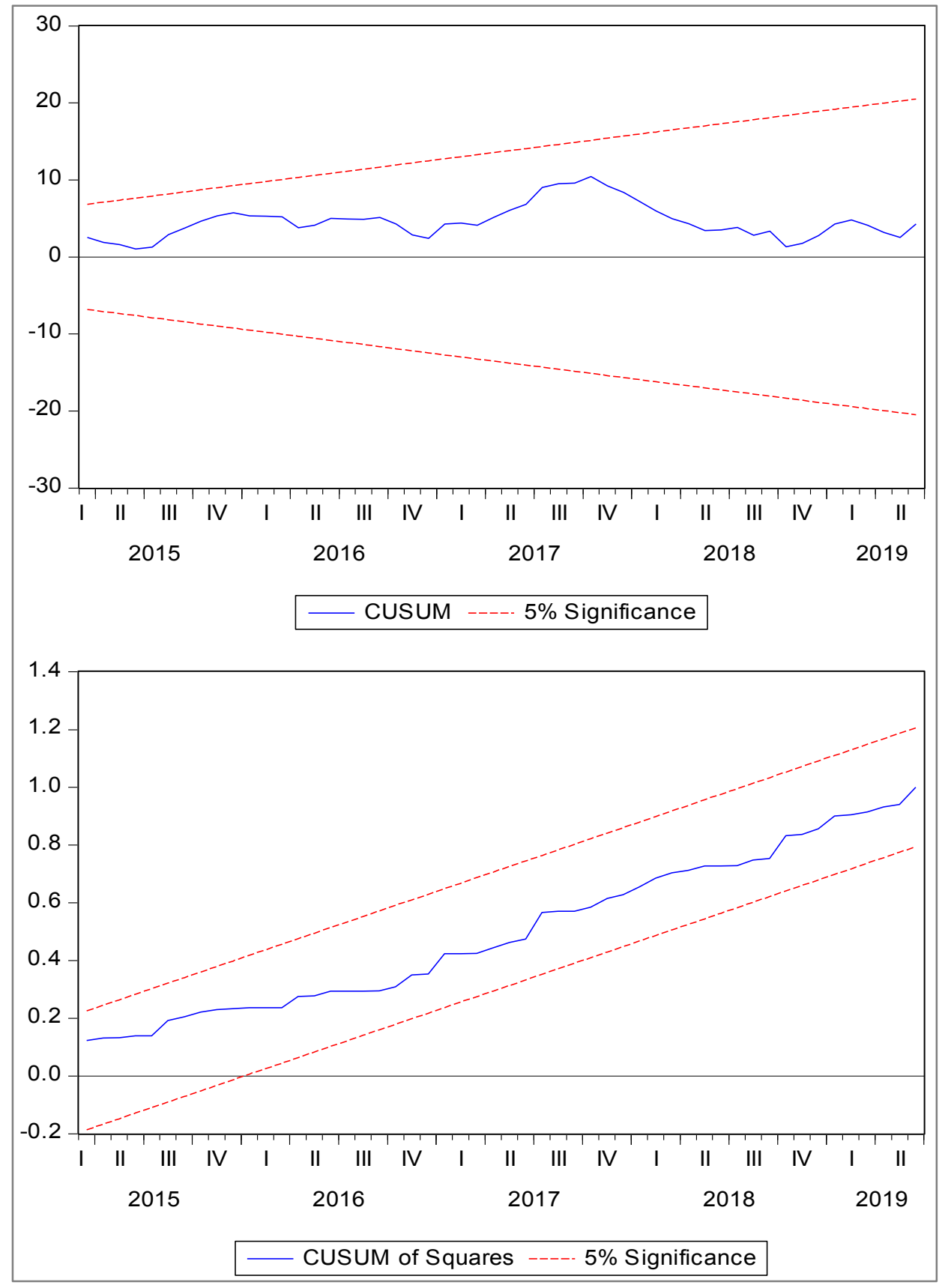

Figure 3. Stability Test Result.

ARDL Model Result

ARDL estimation is done to see the long-term and short-term analysis. Good ARDL results for long-term or short-term can be seen in Table 5. 
Table 5. ARDL Estimation Result.

\begin{tabular}{|c|c|c|c|}
\hline Variable & Coefficient & T-statistic & Prob. \\
\hline \multicolumn{4}{|l|}{ Short Term } \\
\hline D (NPL (-1)) & 0.236793 & 1.905869 & 0.0622 \\
\hline D (NPL (-2)) & 0.338941 & 2.789767 & 0.0074 \\
\hline D (NPL (-3)) & 0.197819 & 1.641391 & 0.1068 \\
\hline D (NPL (-4)) & 0.313949 & 2.708948 & 0.0091 \\
\hline D (IPI) & -0.001696 & -0.859072 & 0.3942 \\
\hline D (IHG) & -0.000035 & -0.663964 & 0.5096 \\
\hline $\mathrm{D}(\mathrm{IHG}(-1))$ & 0.000226 & 3.051828 & 0.0036 \\
\hline $\mathrm{D}(\mathrm{IHG}(-2))$ & -0.000173 & -2.160791 & 0.0353 \\
\hline D (IHG (-3)) & 0.000086 & 1.484057 & 0.1438 \\
\hline $\mathrm{D}(\mathrm{EXH})$ & 0.000046 & 1.336404 & 0.1872 \\
\hline D (EXH (-1)) & 0.000027 & 0.720251 & 0.4746 \\
\hline D (EXH (-2)) & 0.000037 & 0.998526 & 0.3226 \\
\hline D (EXH (-3)) & -0.000008 & -0.234307 & 0.8157 \\
\hline D (EXH (-4)) & -0.000060 & -1.704475 & 0.0943 \\
\hline D (EXH (-5)) & 0.000096 & 2.595197 & 0.0123 \\
\hline D (EXH (-6)) & -0.000113 & -4.043017 & 0.0002 \\
\hline $\mathrm{D}(\mathrm{CPI})$ & 0.001561 & 0.755656 & 0.4533 \\
\hline D (CPI (-1)) & 0.003625 & 1.375997 & 0.1747 \\
\hline D (CPI (-2)) & -0.007854 & -2.833435 & 0.0065 \\
\hline D (CPI (-3)) & 0.002832 & 1.411487 & 0.1641 \\
\hline D (BIR) & -0.042321 & -3.379949 & 0.0014 \\
\hline CointEq (-1) & -0.606287 & -5.265712 & 0.0000 \\
\hline \multicolumn{4}{|l|}{ Long Term } \\
\hline IPI & -0.002798 & -0.845366 & 0.4018 \\
\hline IHG & -0.000036 & -0.980426 & 0.3314 \\
\hline EXH & 0.000142 & 6.123703 & 0.0000 \\
\hline CPI & 0.001390 & 0.768296 & 0.4458 \\
\hline BIR & -0.069803 & -4.841583 & 0.0000 \\
\hline $\mathrm{C}$ & 0.802318 & 2.313699 & 0.0247 \\
\hline R-squared & 0.949869 & & \\
\hline Adj. R-squared & 0.925767 & & \\
\hline F-statistic & 3.941092 & & \\
\hline Prob. (F-statistic) & 0.0000 & & \\
\hline
\end{tabular}

The ARDL model estimation has Adj. R-Squared $92.58 \%$. This shows that macroeconomic variables can explain $92.58 \%$ of changes in credit card NPL of banks. The F-test has a significance level of $<0.05$. It means simultaneous macroeconomic variables significantly affect the credit card
NPL of the Bank. The Dynamic Forecasting result shows the proportion of bias is $0.0044 \%$ (Figure 4 ), which means that the gap between the estimated NPL generated by the model and the actual NPL is very small. This shows the model has a good prediction accuracy.

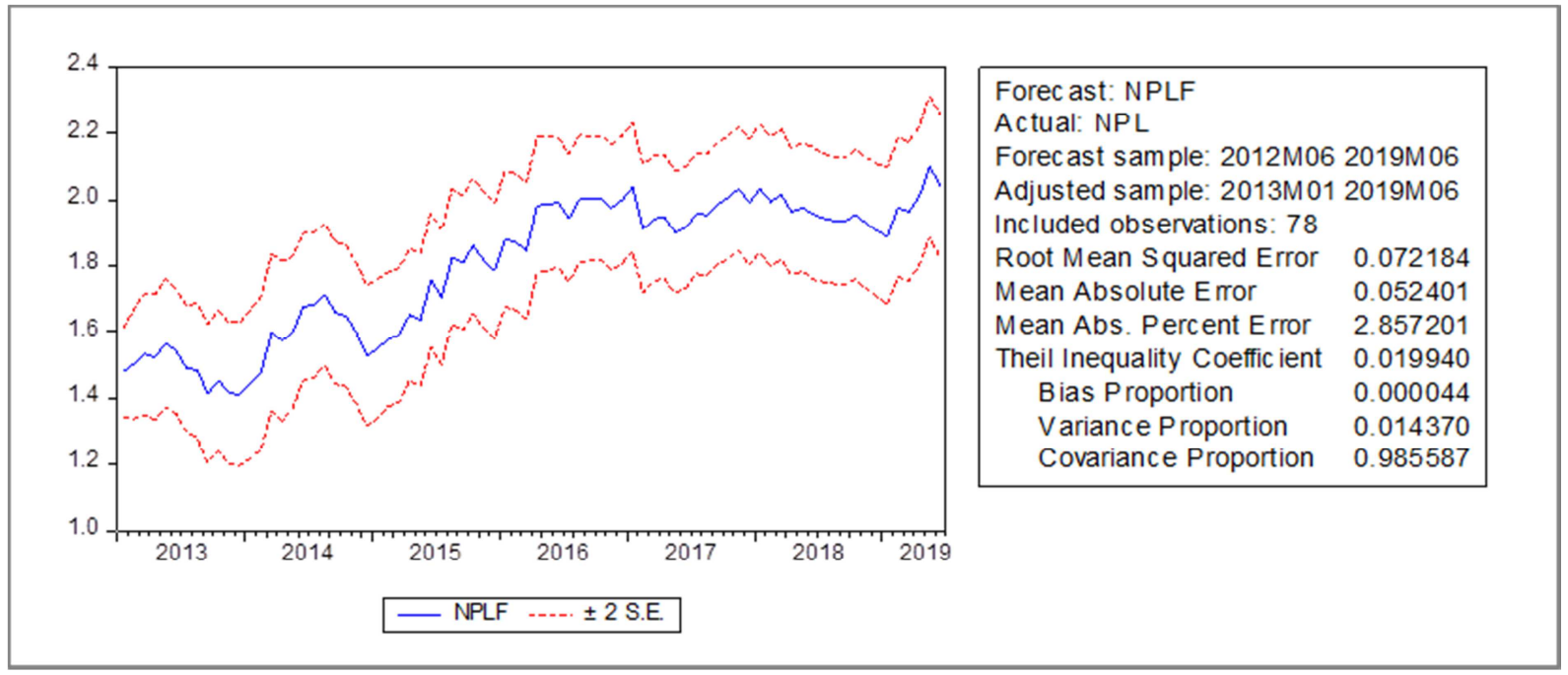

Figure 4. Dynamic Forecasting Result.

Long-term Impact of Macroeconomic Condition on NPL The estimation results of the long-term ARDL model show that the EXH and BIR variables partially have a significant influence on the credit card NPL. Coefficient of independent 
variables in the long-term $<1$. Therefore, the effect of macroeconomic variables is not elastic on the credit card NPL.

EXH has a positive and partially significant effect on credit card NPL. The EXH coefficient of 0.000142 means an increase in EXH (weakening of the IDR against the US Dollar) by $1 \%$ will increase the credit card NPL by $0.000142 \%$. The positive effect of EXH on credit card NPL is supported by a previous study [12]. When the IDR depreciates, imported goods become more expensive, thus affecting the increasing value of the IDR that has to be spent. If a purchase uses a credit card, this will increase the value of the credit card bills to be paid. This condition has the probability to increase the default ratio.

BIR has a negative and partially significant effect on credit card NPL The BIR coefficient is 0.069803 , meaning that an increase in BIR by $1 \%$ will reduce the credit card NPL by $0.069803 \%$. The negative effect of BIR on credit card NPL is supported by a previous study [12]. However, based on the study result $[6,7]$ bank interest rates have a positive influence on credit card NPL. This is because credit card interest rates in Indonesia have been set at a maximum of $26.95 \%$ per year and are not affected by changes in the BI Rate (BIR). In other words, an increase or decrease in BIR will not affect the amount of credit card bills to be paid by the cardholder. On the other hand, changes in BIR will affect the cardholder's decision to use a credit card. Based on the results of the study, if BIR increases, cardholders tend to allocate funds for savings or investment, so that the impact on decreasing the use of credit cards will ultimately reduce the default ratio which is proxied by NPL.

IPI has a negative and not significant effect partially on credit card NPL. IPI coefficient of 0.002798 means that an increase in IPI of $1 \%$ will reduce the credit card NPL by $0.002798 \%$. This is consistent with the study result by $[2,4]$ which states that increasing GDP growth will reduce credit card NPL. IPI is one economic indicator that contributes to GDP. This indicator measures the output of the industrial sector including manufacturing, mining, electricity, and gas. If the production of the industrial sector decreases it will affect the company's financial performance so that it will result in decreased ability to pay for the credit received. Conversely, if the industrial sector production increases will increase company performance so that business owners and employees are more prosperous. Increasing the volume of production will open up new jobs, thereby increasing the people's purchasing power and the ability to pay for the credit received.

IHG has a negative and not significant effect on credit card NPL. IHG coefficient of 0.000036 shows that the effect of the IHG on credit card NPL is very small, an increase in IHG of $1 \%$ will reduce credit card NPL by only $0.000036 \%$. The negative effect of IHG on credit card NPL supported by a previous study [12]. The increase in IHG is one indicator of an increase in the company's financial performance. Good financial performance will improve the welfare of business owners and employees, thereby increasing people's purchasing power and the ability to repay loans received. On the other hand, the increase in IHG gives a good signal to invest, so investors will tend to allocate their finances to invest compared to paying credit card debt. This will have an impact on reducing the use of credit cards, which in turn will reduce the default ratio which is proxied by NPL.

CPI has a positive and not significant effect partially on credit card NPL. The CPI coefficient is 0.001390 , meaning that an increase in CPI of $1 \%$ will increase the credit card NPL by $0.001390 \%$. This is consistent with the study result from [12] which states that an increase in inflation will increase the credit card NPL. CPI is an indicator to measure the inflation rate so that if the CPI rises, inflation also increases. CPI reflects the average price of goods and services consumed by households. Thus, an increase in CPI is a signal of rising prices for goods and services. If purchasing goods and services using a credit card, this will increase the value of the credit card bills to be paid. This condition has the probability to increase the default ratio.

Short-term Impact of Macroeconomic Condition on NPL

According to the estimation results of the ARDL model, in the short-term NPL, IHG, and EXH variables of the previous period, and the current BIR has a partially significant effect on the current credit card NPL. The NPL variable in the previous period had a greater influence than the other variables.

The estimation results of the ARDL model show the Error Correction Term (ECT) has a significant effect, meaning that there is an adjustment mechanism from the short-term to the long-term equilibrium. The ECT coefficient can be interpreted as the speed of adjustment to the long-term equilibrium due to shock in the previous period. The coefficient value is 0.606287 , meaning that the adjustment process to the long-term equilibrium is carried out at $60.63 \%$ per month.

\section{Managerial Implications}

Based on the results of the discussion in the previous section, there are managerial implications that can be used by Bank management in making decisions.

ARDL model influences macroeconomic factors on credit card NPL can be used by Bank as an early warning indicator of the condition of credit card NPL if there is a shock to macroeconomic variables, specifically the BI Rate variable and Exchange Rate. Banks can use this ARDL model to conduct stress testing of credit card NPL regularly. The results of stress testing can provide information on macroeconomic variable shocks that can be accepted by Bank. This acceptable shock can be used as a maximum limit of the amount of credit risk in the credit card portfolio proxied by NPL. Thus, Bank can immediately take the right policy when the macroeconomic variable shocks approach the maximum limit that can be accepted by Bank, so they can anticipate an increase in credit card NPL above Bank risk appetite.

Banks can use macroeconomic variables that have a significant partial effect on the credit card NPL (BI rate and exchange rate) as an indicator of the credit scoring system. This indicator will have the same risk weighting for all new cardholders. When the BI rate decreases or the Exchange Rate weakens, the risk weight of the two indicators increases so that 
the credit scoring system is more conservative than before the shocks to the variable BI rate (decreasing) or Exchange Rate (weakening). This condition can also mean banks become more selective in approving new credit card applications from cardholders. Bank will be very selective when at the same time the BI rate decreases and the exchange rate weakens. Thus, using macroeconomic variables into the credit scoring system is expected to be able to control credit card NPL at Bank, especially from new cardholders.

Macroeconomic variables that have a significant effect on credit card NPL (BI rates and Exchange Rates) can also be used as an indicator of behavior scoring for each of the existing cardholders. The principle is the same as the credit scoring system, the risk weights of the two variables are the same for all existing cardholders. Bank will be more selective in raising credit limits either automatically or based on cardholders' requests and approving the addition of credit card submitted by cardholders. Thus, using macroeconomic variables into behavior scoring is expected to control credit card NPL at Bank, especially those from existing cardholders.

\section{Conclusion}

According to the ARDL model, in the short term, NPL, IHG, EXH variables of the previous period, and the current BIR have a partially significant effect on the current credit card NPL. In the long-term, EXH and BIR variables partially have a significant influence on the credit card NPL. Coefficient of each macroeconomic variable in the long-term $<1$. Therefore, the effect of macroeconomic variables is not elastic on the credit card NPL.

Based on the results of this study, Bank can use the ARDL model of macroeconomic factors that affect credit card NPL as an early warning indicator of the condition of Bank credit card NPL if there is a shock to macroeconomic variables. Besides, macroeconomic factors that significantly influence credit card NPL can be used to improve the feasibility analysis tool for new cardholders (credit scoring system) and an indicator of behavior scoring systems for existing cardholders.

\section{References}

[1] Wilson, Sy. (2007). A Causal Framework for Credit Default Theory. Australian Prudential Regulation Authority.

[2] Kim, Hyeongjun, Cho, Hoon and Ryu, Doojin. (2018). An Empirical Study on Credit Card Loan Delinquency. Economic Systems, 42 (3): 437-449.

[3] Li, Yingying, Li, Ying and Li, Yan. (2019). What Factors are Influencing Credit Card Customer's Default Behavior in China? A study based on survival analysis. Physica A: Statistical Mechanics and Its Applications, 526 (2019): 1-11.
[4] Pettiford, Keith R. (2011). Risk Management and Business Strategy: Macro-Economic Factors Predictive of the Consumer Credit Card Charge-Off Rate [Dissertation]. New Castle: Wilmington University.

[5] Hasan, M. Z. (2019). Causality Between GPD Growth and Non-Performing Loans in Bangladesh: A Toda-Yamamoto Approach. International Journal of Finance and Banking Research, 5 (5): 126-131.

[6] Bellotti, Tonny and Crook, Jonathan. (2009). Credit Scoring with Macroeconomic Variables Using Survival Analysis. The Journal of The Operational Research Society, 60 (12): 1699-1707.

[7] Bellotti, Tonny and Crook, Jonathan. (2013). Forecasting and Stress Testing Credit Card Default Using Dynamic Models. International Journal of Forecasting, 29 (2013): 563-574.

[8] Agarwal, Sumit and Liu, Chunlin. (2003). Determinants of Credit Card Delinquency and Bankruptcy: Macroeconomic Factors. Journal of Economics and Finance, 27 (1): 76-84.

[9] Bellotti, Tonny and Crook, Jonathan. (2012). Loss Given Default Models Incorporating Macroeconomic Variables for Credit Cards. International Journal of Forecasting, 28 (2012): 171-182.

[10] Soh, Weini. (2019). Non-Performing Loan and Economic Determinants in Asia-Pacific Countries: Evidence from Credit Card Debt. International Journal of Recent Technology and Engineering, 7 (16): 9-14.

[11] Gross, David B. and Souleles, Nicholas S. (2002). An Empirical Analysis of Personal Bankruptcy and Delinquency. The Review of Financial Studies., 15 (1): 319-347.

[12] Maruli, Jonathan. (2010). Variabel Makroekonomi yang Berpengaruh terhadap Tingkat Non-Performing Loan Kartu Kredit (Studi Kasus di Bank X) [Tesis]. Jakarta: Universitas Indonesia.

[13] Gujarati, Damodar N. and Porter, Dawn C. (2012). Dasar-Dasar Ekonometrika: Edisi 5. Jakarta [ID]: Salemba Empat.

[14] Nkoro, Emeka and Uko, Aham Kelvin. (2016). Autoregressive Distributed Lag (ARDL) cointegration technique: application and interpretation. Journal of Statistical and Econometric Methods, 5 (4): 63-91.

[15] Pesaran, M. Hashem and Shin, Yongcheol. (1995). An Autoregressive Distributed Lag Modelling Approach to Cointegration Analysis. Econometrics and Economic Theory in the 20th Century: The Ragnar Frisch Centennial Symposium.

[16] Pesaran, M Hashem, Shin, Yongcheol and Smith, Richard J. (2001). Bound Testing Approaches to the Analysis of Level Relationships. Journal of Applied Econometrics, 16 (2001): 289-326.

[17] Brown, R. L., Durbin, J. and Evan, J. M. (1975). Techniques for Testing the Constancy of Regression Relationships over Time. Journal of the Royal Statistical Society Series B (Methodological), 37 (2): 149-192. 